OPEN ACCESS

Edited by:

Suzie Chen,

Rutgers, The State University of New Jersey, United States

Reviewed by:

Mohammad Zubair Alam, King Abdulaziz University,

Saudi Arabia

Mohd Ikram Ansari,

Indian Veterinary Research Institute (IVRI), India

*Correspondence: Farazul Haque catchfaraz@gmail.com; haque.farazul.2r@kyoto-u.ac.jp Mohd Sajjad Ahmad Khan khanmsa@hotmail.com; mskhan@iau.edu.sa

Specialty section: This article was submitted to Cancer Molecular

Targets and Therapeutics, a section of the journal Frontiers in Oncology

Received: 28 October 2020 Accepted: 20 January 2021 Published: 16 March 2021

Citation:

Haque F, Khan MSA and A/Qurashi N (2021) ROS-Mediated Necrosis by Glycolipid Biosurfactants on Lung, Breast, and Skin Melanoma Cells.

Front. Oncol. 11:622470. doi: 10.3389/fonc.2021.622470

\section{ROS-Mediated Necrosis by Glycolipid Biosurfactants on Lung, Breast, and Skin Melanoma Cells}

\author{
Farazul Haque ${ }^{1 *}$, Mohd Sajjad Ahmad Khan ${ }^{2 *}$ and Naif AlQurashi ${ }^{2}$ \\ ${ }^{1}$ Department of Immunology and Genomic Medicine, Graduate School of Medicine, Kyoto University, Kyoto, Japan, \\ 2 Department of Basic Sciences, Deanship of Preparatory Year and Supporting Studies, Imam Abdulrahman Bin Faisal \\ University, Dammam, Saudi Arabia
}

Cancer is one of the major leading causes of death worldwide. Designing the new anticancer drugs is remained a challenging task due to ensure complexicity of cancer etiology and continuosly emerging drug resistance. Glycolipid biosurfactants are known to possess various biological activities including antimicrobial, anticancer and antiviral properties. In the present study, we sought to decipher the mechanism of action of the glycolipids (lactonic-sophorolipd, acidic-sophorolipid, glucolipid, and bolalipid) against cancer cells using lung cancer cell line (A549), breast cancer cell line (MDA-MB 231), and mouse skin melanoma cell line (B16F10). Scratch assay and fluorescence microscopy revealed that glycolipids inhibit tumorous cell migration possibly by inhibiting actin filaments. Fluorescence activated cell sorter (FACS) analysis exhibited that lactonic sophorolipid and glucolipid both induced the reactive oxygen species, altered the mitochondrial membrane potential $(\Delta \Psi)$ and finally led to the cell death by necrosis. Furthermore, combinatorial effect of lactonic-sophorolipd and glucolipid demonstrated synergistic interaction on A549 cell line whereas additive effect on MDA-MB 231 and B16F10 cell lines. Our study has highlighted that lactonic-sophorolipd and glucolipid could be useful for developing new anticancer drugs either alone or in combination.

Keywords: cancer, glycolipids, mitochondria membrane potential, necrosis, reactive oxygen species, synergy

\section{INTRODUCTION}

Surfactants are the compounds that alter the surface and interfacial tension at air/liquid or liquid/ liquid interfaces. They are broadly devided into two categories, i.e., chemical and biological. Chemically derived surfactants play a crucial role in our daily life, although, these surfactants have several drawbacks over biologically derived surfactants or biosurfactants (BSs) (1). BSs have gained special interest due to their superior quality and potentialities to overcome the disadvantages of chemical surfactants. BSs are a group of diverse amphiphilic compounds and could be widely used in cosmetics, pharmaceuticals, food industries, and bioremediation (2). The most biologically active class of BSs are glycolipids (3). The glycolipids have gained focus by researchers due to their superior pharmaceuticals properties. The glycolipids (viz. sophorolipid, rhamnolipid etc.), like other BSs, can be easily produced by using cheap agri-wastes, used oil from restaurants or animal fats using fermentation processes. Glycolipids have become a possible alternative to be effectively utilized in 
pharmaceutical, food, biomedical, and health industries due to its exceptional biological activities such as antimicrobial, antiviral, anticarcinogenic, and immne-modulating potentials (4).

BSs like sophorolipid (SL), rhamnolipid, trehalolipid, and mannosylerythritol lipid (MEL) are the most important glycolipids found in nature. MEL is known for its antimicrobial, immunological, and neurological activities (5-7). Moreover, MEL has shown chromatin condensation, DNA fragmentation, cell cycle arrest, and production of melanin in B16F10 mouse melanoma cells which leads to apoptosis or cell death (8). The SL produced by Wickerhamiella domercqiae was shown to induce apoptosis in H7402 human liver cancer cells by blocking the cell cycle at G1 phase, activating caspase-3, and increasing $\mathrm{Ca}^{2+}$ concentration in the cytoplasm (9). The effects of different lengths of sophorolipid moleculeson human esophageal and pancreatic cancer cell lines, were also studied $(10,11)$. Glycolipid from Sphingobacterium detergens showed anticancer activity against $\mathrm{Caco} 2$ colorectal cancer cell line (12). On the other hand, trehalose lipid, a glycolipid from Mycobacteria is useful in the bioremediation and also act as an antitumor agent (13). Recently, our lab also showed that lactonic SL has antifungal activity by ROS generation and ultimately cell death by necrosis $(14,15)$. Whereas, rhamnolipid has shown antimicrobial activity alone or in combination with nisin (16). Nevertheless, these effects were not deeply investigated as many researchers concluded their results based on single cell line without using proper controls (non-cancer cell lines) (17).

Cancer is the second leading cause of death globally, accounting for an estimated 9.6 million deaths. Lung, prostate, colorectal, stomach, and liver cancers are the most common types of cancer in men, whereas breast, colorectal, lung, cervical, and thyroid cancers are the most common among women (18). Cancer of lung, liver, breast, stomach, and bowel are the most common cause of death worldwide. Lung cancer related death is ranking at the top followed by breast cancer (http://www.cancerresearchuk.org). Globally, 1.38 million new cases of breast cancer are diagnosed every year. Around 458,000 death from breast cancer occures per year worldwide, making it the most common cause offemale cancer death in both developed and developing world (19). The reasons for the increased death rate are non-specific targets of anticancer molecules that causes severe side effects, and low cure rates (20) as well as resistance attained by cancer cells (21).

Considering the current scenario it is urgently required to develop highly specific and less toxic molecules for the anticancer therapy. Therefore, in our present study, we investigated anticancer efficacy of four different types of glycolipids, viz. acidic SL, lactonic SL, glucolipid, and bolalipid on three different cancer cell lines, i.e., lung (A549), breast (MDA-MB231), and mouse melanoma cell line (B16F10). We attempted to explore the mechanism of action of these glycolipids. Moreover, combinatorial effects between potential glycolipids were also evaluated. In our knowledge, this is the first report exhibiting the detailed mechanistic view of glycolipids on cancer cell lines as well as combinatorial effects when used in combination. This study could be useful in developing glycolipids as newer anticancer drugs.

\section{MATERIALS AND METHODS}

\section{Biosurfactants, Cell Lines, and Media}

Both acidic and lactonic forms of SL were produced by our lab standardized protocol $(7,15)$. Whereas, bolalipid and glucolipids were synthesized by previously published protocols as adapted by Serens et al. (22) and Delbeke et al. (23). The human lung adenocarcinoma epithelial cell line A549, breast cancer cell line MDA-MB231 and mouse skin melanoma cell line B16F10 as well as normal human fibroblast cells MRC-5 were purchased from ATCC (American Type Culture Collection). A549 cells were maintained in DMEM (sigma) supplemented with $10 \%$ fetal bovine serum (FBS) (Sigma), $100 \mathrm{IU} / \mathrm{ml}$ penicillin and $100 \mu \mathrm{g} / \mathrm{ml}$ streptomycin in humidified $5 \% \mathrm{CO}_{2}$ at $37^{\circ} \mathrm{C}$. MDA-MB231 cells were cultured in DMEM supplemented with $6 \mathrm{mM}$ L-glutamine, $20 \mathrm{mM}$ Hepes, $10 \mu \mathrm{g} / \mathrm{ml}$ human insulin, 10\% (vol/vol) FBS, 100 units $/ \mathrm{ml}$ penicillin and $100 \mu \mathrm{g} / \mathrm{ml}$ streptomycin at $37^{\circ} \mathrm{C}$, in $5 \%$ $\mathrm{CO}_{2}$. B16F10 cell line was cultured and maintained in Dulbecco's-modified Eagle's medium (DMEM) (Sigma) supplemented with $10 \%$ fetal bovine serum (FBS), and incubated at $37^{\circ} \mathrm{C}$ in a $95 \% \mathrm{O}_{2}$ atmosphere.

\section{Cytotoxicity/MTT Assay}

The cytotoxic effects of glycolipids were assessed against the cancer cell lines by MTT [3-(4,5-dimethylthiazol-2-yl)-2,5diphenyltetrazolium bromide] assay. Briefly, $15 \times 10^{3}$ cells of cell line suspensions per well of a 96-well plate were seeded and allowed to adhere for $12-16 \mathrm{~h}$. Varying concentrations $(0-1,000$ $\mu \mathrm{g} / \mathrm{ml}$ ) of test glycolipids were made in Dimethylsulfoxide (DMSO). The concentration were made such that the final amount of DMSO should not exceed $0.2 \%$ and later added to the wells. After incubation for $24 \mathrm{~h}$ and $48 \mathrm{~h}$, cell viability was detrmined by using MTT. A solution containing $10 \mu \mathrm{l}$ of MTT and $90 \mu \mathrm{l}$ of media was added to each wells and the cells were incubated for another $3 \mathrm{~h}$ at $37^{\circ} \mathrm{C}$ with $5 \% \mathrm{CO}_{2}$. Later, solution containing media and MTT were taken out and $100 \mu \mathrm{l}$ of DMSO (100\%) was added to each well and mixed properly to dissolve the purple formazon crystals. The dissolved crystals were measured by spectrophotometry at $570 \mathrm{~nm}$ using microplate reader (Multiskan MK3, Thermo Lab systems). The cytotoxicity of glycolipids were expressed as a value of $\mathrm{IC}_{50}$ (The concentrations where $50 \%$ of the cell are dead). The effect of glycolipids on non-cancerous fibroblast cells (MRC-5) was also evaluated. Etoposide $10 \mathrm{nM}$ (Sigma) used as a positive control.

\section{In Vitro Scratch Assay/Migration Assay}

In vitro cell migration assay was performed in 12 well plates using a scratch method as adapted by Liang et al. (24). Briefly, $1 \times$ $10^{5}$ cells of cell line suspensions were seeded in 12 well plates and allowed to adhere at $37^{\circ} \mathrm{C}$ with $5 \% \mathrm{CO}_{2}$ until the complete monolayer is formed. Scratch was inflicted using the sterile toothpick. The medium was carefully removed and cells were washed three times with PBS. Further, $700 \mu$ of serum free media with glycolipids or control ( $0.2 \%$ DMSO dissolved in media) was added. At $0 \mathrm{~h}, 24 \mathrm{~h}$, and $48 \mathrm{~h}$, wound were observed and photographed. Relative migration area, expressed in 
percentage, was obtained from equation 1 where, $A_{t}$ represents the final cell free area, and $A_{\text {to }}$ stands for initial wound area.

$$
R T=A_{t} \times 100 / A_{t o}
$$

\section{Immunofluorescence Assay}

All three cancer cells were seeded on sterilized lysine coated cover slips (lodged in a 12 well plate) in the number of $1 \times 10^{5}$ cells, in their appropriate complete growth medium. Cells were allowed to attach for $12 \mathrm{~h}$ at $37^{\circ} \mathrm{C}$ until it forms a complete monolayer on the coverslip. After $24 \mathrm{~h}$ of glycolipids treatment, cells were washed with PBS. Later, formalin was added to each well for $20 \mathrm{~min}$ for proper fixation. Subsequently, formalin is aspirated out and cells were washed with PBS three times, followed by blocking with $1 \%$ bovine serum albumin (BSA) at room temperature for next $1 \mathrm{~h}$. Next, cells were stained with FITC-phalloidin antibody $(1: 100 \mathrm{v} / \mathrm{v})$ and incubated at $4^{\circ} \mathrm{C}$ overnight. Then, after washing with PBS three times, cells were counterstained with 4',6-diamidino-2-phenylindole (DAPI) $(1: 1000 \mathrm{v} / \mathrm{v})$ for $10 \mathrm{~min}$. Phalloidin has a strong affinity toward actin filaments. Phalloidin tagged with fluorescent dye binds to actin and appears red in color whereas DAPI stained the nucleus and appears blue. Slides were prepared by mounting the coverslips in histamount (Sigma) and observed under Zeiss fluoresecence microscope (100× magnification) to observe the distribution of F-actin. Etoposide $(10 \mathrm{nM})$ was used as positive control.

\section{Reactive Oxygen Species (ROS) Measurement}

To determine baseline intracellular ROS levels, approximately $5 \times 10^{4}$ cells were seeded in each well of 24 well plates and incubated at $37^{\circ} \mathrm{C}$, with $5 \% \mathrm{CO}_{2}$ for $24 \mathrm{~h}$. Later, media was aspirated out and cells were washed with PBS three times, and fresh medium containing various concentrations of glycolipids was added and plates were incubated at $37^{\circ} \mathrm{C}$ for $3 \mathrm{~h}$ (DMSO $0.2 \%$ was used as vehicle control). After incubation, media was gently removed and ROS-specific dye $\mathrm{H}_{2}$-DCFDA (10 $\mu \mathrm{M}$ in PBS) was added for $10 \mathrm{~min}$ and incubated for $15 \mathrm{~min}$ at $37^{\circ} \mathrm{C}$. Next, dye was removed and cells were washed and $0.1 \%$ of trpysin solution in PBS was added. Finally, the cells were collected and acquired using flow cytometer (Beckman coulter, Gallios FACS).

\section{Mitochondria Membrane Potential (MMP) Measurement}

The change of mitochondrial membrane potential was determined by the retention of the dye $3,3^{\prime}$ Dihexyloxacarbocyanine iodide $\left(\mathrm{DiOC}_{6}\right)$ using the method of Liu et al. (25). Briefly, $15 \times 10^{3}$ cells were seeded in each well of the 96-well plate overnight prior to the experiments. Next day, cells were treated with different concentrations of glycolipids for $48 \mathrm{~h}$. After treatment, cells were harvested, washed twice with PBS and stained with $50 \mathrm{nM} \mathrm{DiOC}{ }_{6}$ at $37^{\circ} \mathrm{C}$ for $30 \mathrm{~min}$. Cells were then washed again, resuspended in $0.5 \mathrm{ml}$ of PBS and analyzed by FACS (Beckman Coulter) at FL-1 channel.

\section{Acridine Orange/Ethidium Bromide (AO/EB) Dual Staining}

To determine the morphological evidence of necrosis/apoptosis in glycolipid treated cells, $\mathrm{AO} / \mathrm{EB}$ staining was carried out by the method of Kasibhatla et al. (26). Briefly, cells with the density of 1 $\times 10^{5}$ were grown on 12 well plates with lysine coated glass cover slips until they form the complete monolayer. Afterward, cells were treated with various concentrations of glycolipids for $24 \mathrm{~h}$ and $48 \mathrm{~h}$ and subsequently washed with PBS as described above. Finally, treated and untreated cells were stained with acridine orange and ethidium bromide cocktail $(100 \mu \mathrm{g} / \mathrm{ml}$ each of acridine orange and ethidium bromide mixed in PBS). Samples were examined under fluorescence microscopy (Zeiss Axio scope A1).

\section{Apoptosis Assay}

The morphological figures of apoptotic/necrotic cells death was studied using annexin V-FITC and propidium iodide (PI) double staining apoptotic assay (Life Technology) as adapted by Rieger et al. (27). Briefly, $3 \times 10^{5}$ cells were seeded into 6 wells and incubated for overnight. Later culture plate is treated with different concentrations of glycolipids for $48 \mathrm{~h}$. Subsequently, cells were typsinized, centrifuged and pellets were washed with cold PBS. Cells were suspended in $500 \mu \mathrm{l}$ annexin binding buffer together with $5 \mu \mathrm{l}$ of annexin V-FITC 488 and incubated for $5 \mathrm{~min}$. After the incubation, $1 \mu \mathrm{l}$ of PI $(100 \mu \mathrm{g} / \mathrm{ml})$ was added to the cells and incubated for $5 \mathrm{~min}$. Finally, cells were acquired by FACS (Bekman coulter) at FL-1 channel.

\section{Drug-Drug Interaction by Checkerboard Assay}

Combinatorial effect of glycolipids was evaluated against the cancer cells by checkerboard method. Firstly, cancer cells were grown at a density of $15 \times 10^{3}$ cells per well of 96-well plates. Secondly, serial double diluted concentration of L-SL $(0-100 \mu \mathrm{g} /$ $\mathrm{ml})$ and Glucolipid $(0-1000 \mu \mathrm{g} / \mathrm{ml})$ were prepared in DMEM medium. Further, $10 \mu \mathrm{l}$ of each glycolipid dilution was dispensed into 96 well plate microtiter plates. Next, glycolipid dilution made in the separate plate were transfered to plates containing cells and plates were incubated at $37^{\circ} \mathrm{C}$ with $5 \% \mathrm{CO}_{2}$ for $24 \mathrm{~h}$. After the incubation, $10 \mu \mathrm{l}$ of MTT was added and plates were incubated for $3 \mathrm{~h}$. Afterward, media were aspirated out and 100 $\mu \mathrm{l}$ of DMSO was added as described above and plates were read at $600 \mathrm{~nm}$. The value $\leq 0.5$ showed the synergistic interaction whereas value more than $>0.5$ and $\leq 4$ showed the additive effect.

\section{RESULTS}

\section{Effect of Glycolipids on Cell Viability}

A549, MDA-MB 231, and B16F10 cell lines were treated with glycolipids (acidic SL, lactonic SL, glucolipid, and bolalipid) at concentrations mentioned for $24 \mathrm{~h}$ and $48 \mathrm{~h}$ (Figures 1A, B). For acidic SL and bolalipid, we did not observed any change in cell viability on any cell lines used in the study (Figure 1B; Supplementary Figure 1) both after $24 \mathrm{~h}$ and $48 \mathrm{~h}$ of 
treatment. However for L-SL, $\mathrm{IC}_{50}$ values against A549, MDA$\mathrm{MB} 231$, and B16F10 cell lines were 50, 50, and $40 \mu \mathrm{g} / \mathrm{ml}$, respectively. Whereas, in presence of glucolipid, $\mathrm{IC}_{50}$ values against A549, MDA-MB 231 and B16F10, were 850, 900, and $600 \mu \mathrm{g} / \mathrm{ml}$, respectively. L-SL at $100 \mu \mathrm{g} / \mathrm{ml}$, completely killed A549 and MDA-MB231 cells but not the B16F10 cells. After $48 \mathrm{~h}$ of L-SL treatment, the $\mathrm{IC}_{50}$ values were reduced to $40 \mu \mathrm{g} / \mathrm{ml}$ for A549 and MDA-MB231, and around $35 \mu \mathrm{g} / \mathrm{ml}$ for B16F10. Moreover, $48 \mathrm{~h}$ treatment of glucolipid resulted in the reduction of $\mathrm{IC}_{50}$ value to $400 \mu \mathrm{g} / \mathrm{ml}$ against both $\mathrm{A} 549$ and MDM-MB231 and $100 \mu \mathrm{g} / \mathrm{ml}$ against B16F10. However, The effect of glycolipids on MRC-5 cells (normal fibroblast) were also evaluated (Supplementary Figure 1). Interestingly, we were unable to find the $\mathrm{IC}_{50}$ value for $\mathrm{L}-\mathrm{SL}$ whereas glucolipid showed cytotoxic effects on MRC-5 cells (Table 1,
Supplementary Figure 1). Furthermore, we selected lactonicsophorolipid (L-SL, $50 \mu \mathrm{g} / \mathrm{ml}$ ) and glucolipid (G, $500 \mu \mathrm{g} / \mathrm{ml}$ ) concentrations in all the subsequent experiments unless stated.

\section{Glycolipids Inhibit the Migration of Cancer Cells}

The scratch assay was done to observe the migration of the cancer cells in vitro. After $24 \mathrm{~h}$ of treatment with L-SL at $50 \mu \mathrm{g} /$ $\mathrm{ml}$ (L-SL50), the relative migration of MDA-MB231, A549 and B16F10 were reduced to $84.74 \%, 54.54 \%$, and $22.85 \%$, respectively, compared to DMSO control (Figure 2; Supplementary Figure 2). Whereas, glucolipid at $500 \mu \mathrm{g} / \mathrm{ml}$ (G500), relative migration with respect to control were $84.74 \%$, $27.27 \%$, and $5.714 \%$ for MDA-MB231, A549, and B16F10, respectively. Relative migration of the cells after $48 \mathrm{~h}$ of

A

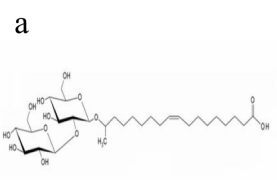

Acidic-Sophorolipid

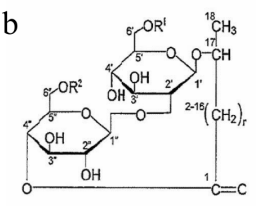

Lactonic-Sophorolipid c

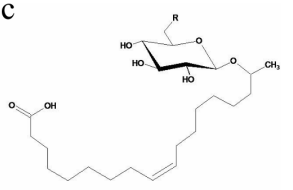

Glucolipid

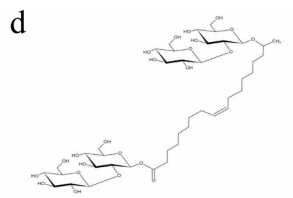

Bolalipid
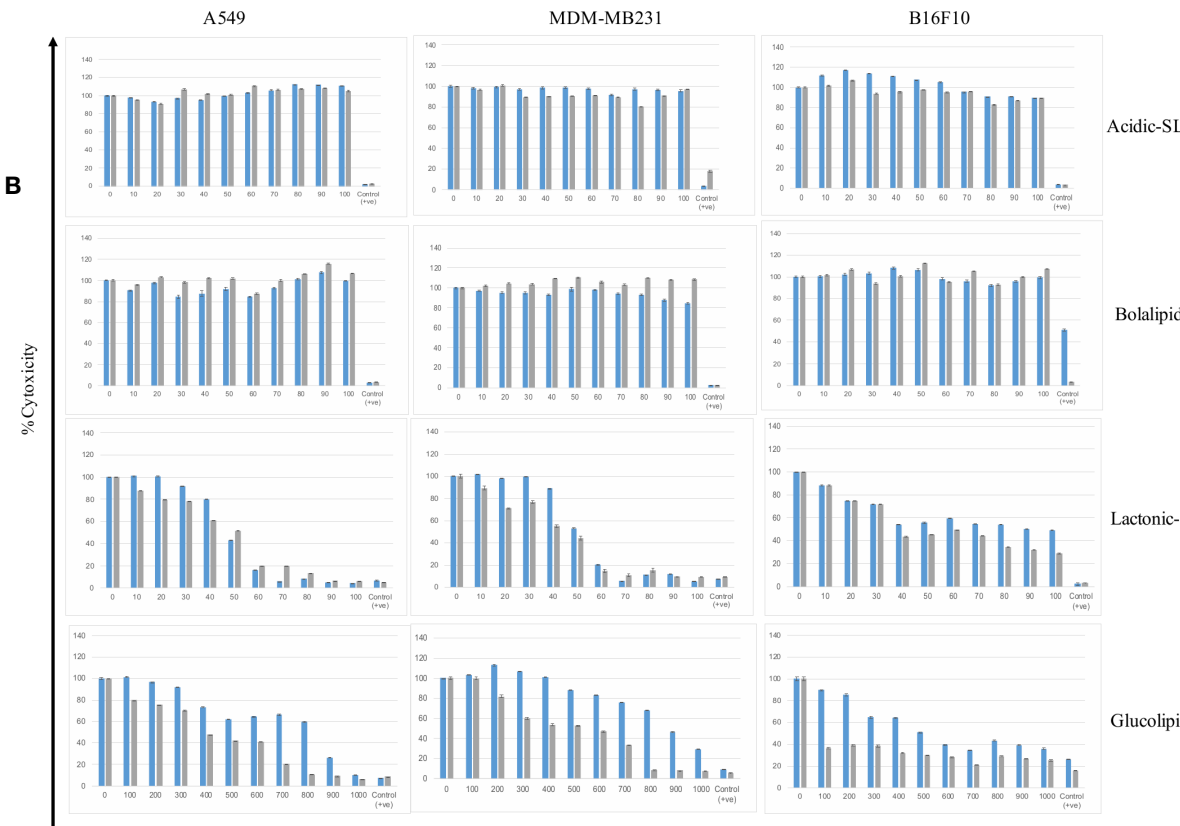

(n)
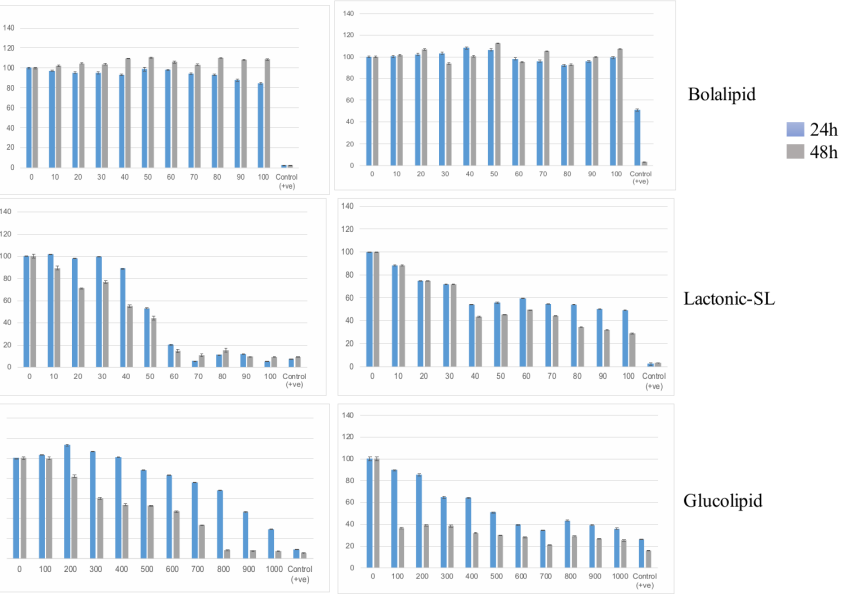

Concentration $(\mu \mathrm{g} / \mathrm{mL})$

FIGURE 1 | (A) The putative structures of different glycolipid biosurfactants used in the present study: (a) Acidic sophorolipid (A-SL); (b) Lactonic sophorolipid (L-SL); (c) Glucolipid; (d) Bolalipid (B). The cytotoxic effect of glycolipid biosurfactants on different cancerous cell lines for $24 \mathrm{~h}$ and $48 \mathrm{~h}$ of treatment. The figure has been plotted in respect to DMSO vehicle control and has been done six times in three independent days, and the mean value has been shown. Statistical significance between treated and control groups was analyzed by Student's test (two-tailed, unequal variance). A p-value of $<0.05$ was considered statistically significant. Etoposide (10 nM) concentration was used as positive control. 
TABLE 1 | Toxic effects $\left[{ }^{1} \mathrm{C}_{50}(\mu \mathrm{g} / \mathrm{mll})\right]$ of glycolipids on different cancer cell lines.

\begin{tabular}{|c|c|c|c|c|c|c|c|c|}
\hline \multirow[t]{2}{*}{ Cell lines } & \multicolumn{2}{|c|}{ Lactonic -SL } & \multicolumn{2}{|c|}{ Glucolipid } & \multicolumn{2}{|c|}{ Acidic -SL } & \multicolumn{2}{|c|}{ Bolalipid } \\
\hline & $24 \mathrm{~h}$ & $48 \mathrm{~h}$ & $24 \mathrm{~h}$ & $48 h$ & $24 \mathrm{~h}$ & $48 h$ & $24 \mathrm{~h}$ & $48 \mathrm{~h}$ \\
\hline A549 & 50 & 40 & 850 & 400 & ND & ND & ND & ND \\
\hline MDA-MB231 & 50 & 40 & 900 & 400 & ND & ND & ND & ND \\
\hline B16F10 & 40 & 35 & 600 & 100 & ND & ND & ND & ND \\
\hline MRC-5 & ND & 90 & 550 & 400 & ND & ND & ND & ND \\
\hline
\end{tabular}

ND, not detected.

treatment was also observed. In the presence of L-SL50 migration were $90.36 \%, 63.36 \%$, and $25 \%$ in MDA-MB231, A549, and B16F10, respectively. Whereas, at G500 after $48 \mathrm{~h}$, relative migration were observed to be $66.26 \%, 18.98 \%$, and $5 \%$ for MDA-MB231, A549, and B16F10, respectively. Etoposide (25 $\mathrm{nM}$ ) was used as a positive control.

\section{Effect of Glycolipids on Actin Filaments}

The effect of glycolipids on actin filaments was tested by ZO1/ phalloidin assay. Treatment with G500 and L50 has resulted in the loosening of actin filaments in A549, MDA-MB231 and B16F10 cells whereas DMSO control cells showed dense network of actin filaments attached to each other (Figure 3). L50 was highly effective against all the cancer cells. Treatment of G500 was highly effective against the B16F10 cells whereas MDAMB231 showed moderate resistance toward it. No actin filaments were observed when treated with L-SL50.

\section{Reactive Oxygen Species Production in the Presence of Glycolipids}

The effect of glycolipids on ROS production in the cancer cells were estimated by FACS and flurometric analysis. The result has demonstrated that after $3 \mathrm{~h}$ of treatment with G500 as well as LSL50 both induced the ROS production in all the cancer cells. In the case of A549, 16.92\% and $22.72 \%$ of the cells showed ROS at G500 and L-SL50, respectively. Whereas, in B16 F10 cells, $14.02 \%$ and $21.46 \%$ of the cells showed the ROS production at
G500 and L-SL50. MDA-MB231 showed the negligible ROS production even at the maximum concentrations tested for glycolipids (Figure 4A). We also tested the ROS production by using the lesser concentrations of lactonic-SL and Glucolipid (30 $\mu \mathrm{g} / \mathrm{ml}$ and $300 \mu \mathrm{g} / \mathrm{ml}$, designated as L30 and G300, respectivily) as small doses of coumpounds are sufficient for ROS production. We observed dose dependent increase in the ROS radicals in all the cell lines used, which is also directly correlating with the FACS data (Figures 4A, B).

\section{Mitochondria Membrane Potential (MMP) Difference in the Presence of Glycolipids}

The effect of glycolipids on MMP of different cancer cell lines was also evaluated. A significant difference was observed in MMP for all the tested cell lines, when treated with G500 and L-SL50. Depolarization was detected in the case for A549 cells when treated with both the glycolipids compared to DMSO control treated cells. In B16F10, hyper-polarization was observed when treated with G500 and depolarization when L-SL50 was used. MDA-MB231 cells showed little hyperpolarisation when treated with G500 and cause depolarization when treated with L-SL50 (Figure 5).

\section{Effect of Glycolipids on Cancer Cells (Live/ Dead Staining)}

Acridine orange and ethidium bromide (AO/EB) dual staining was used to determine apoptosis/necrosis the glycolipid treated

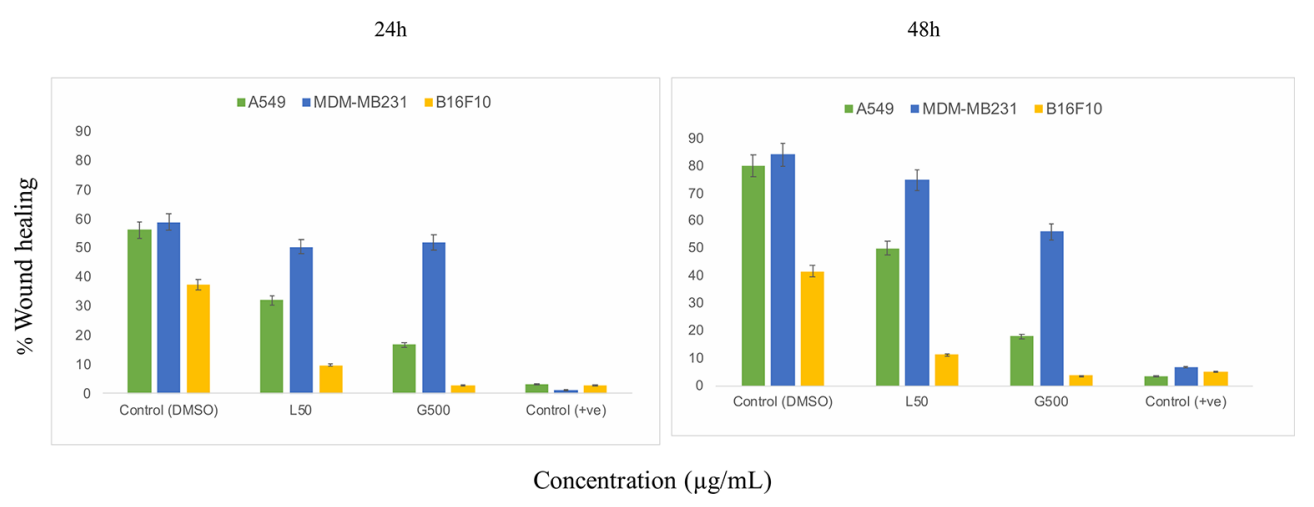

FIGURE 2 | In vitro cancer cell migration in the presence of glycolipids after $24 \mathrm{~h}$ and $48 \mathrm{~h}$ of treatment with respect to DMSO control (0.2\%, as a vehicle control). L50 (Lactonic SL $50 \mu \mathrm{g} / \mathrm{mL}$ ) and Glucolipid (G500 $\mu \mathrm{g} / \mathrm{mL}$ ) concentration has been chosen for the experiment. Etoposide (10nM) concentration was used as a positive control. The scratch area has been measured by imageJ software. Data are presented as the average of three independent experiments \pm SD. All the values are statistically significant $(\mathrm{p}<0.05)$ when compared with glycolipid DMSO control. 


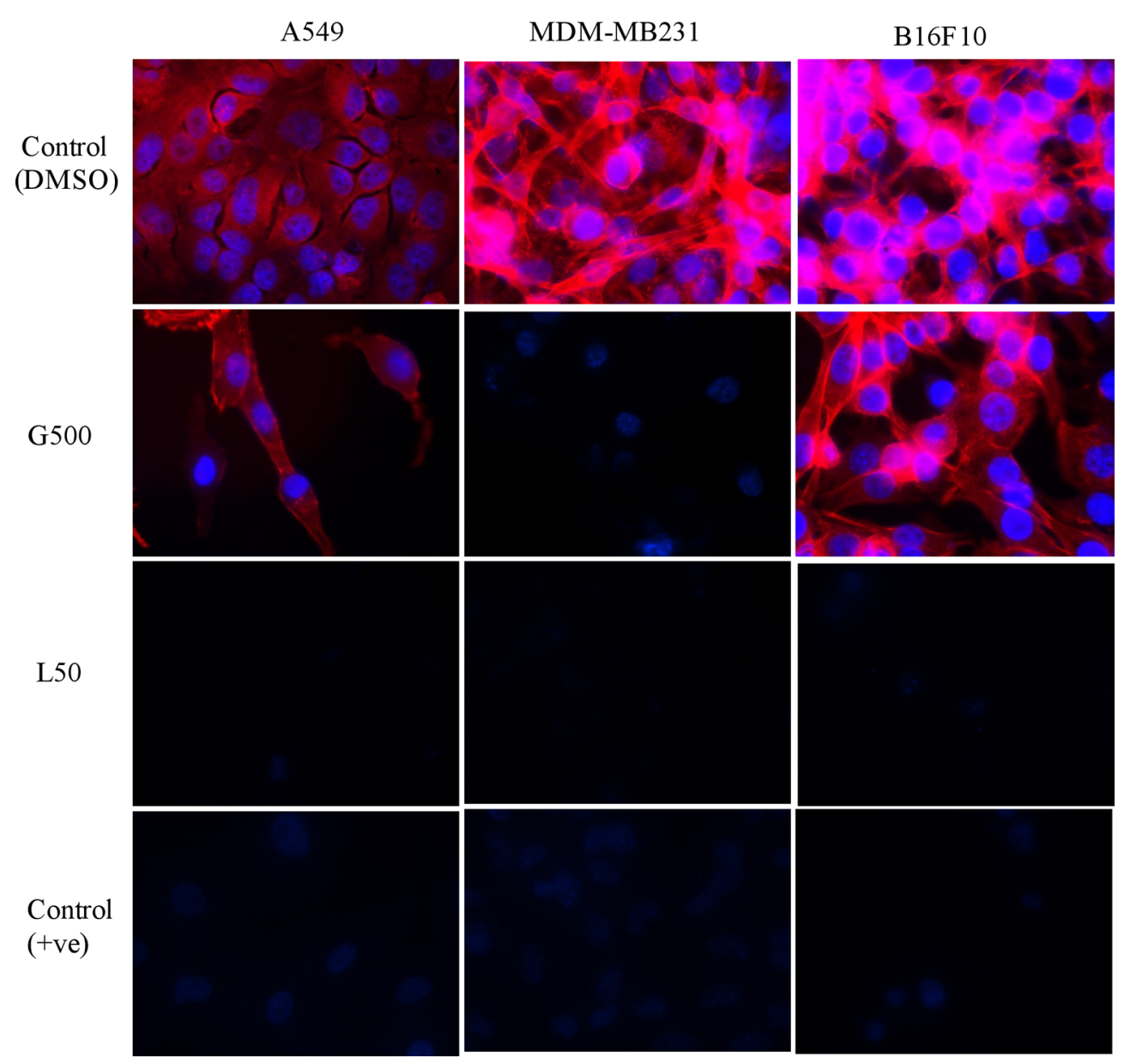

FIGURE 3 | The effect of glycolipids biosurfactant on actin cytoskeleton. Cancer cells were treated with L50 (Lactonic SL $50 \mu \mathrm{g} / \mathrm{mL})$ and Glucolipid (G500 $\mu \mathrm{g} / \mathrm{mL})$ concentration and stained with anti-phyllodin antibodies to visualize the actin filament and 4',6-diamidino-2-phenylindole (DAPI) to visualize nucleus. Photograph was taken at 100X magnification by flourescence microscopy. Etoposide (25nM) was used as a positive control, whereas DMSO was used as vehicle control. The experiment has been performed three times on three independent days.

samples. Cancer cells were treated with L-SL50 and G500 for 24 h. G500 treated MDA-MB231 cells appeared red in color indicating dead or necrosed cells. Whereas, for L-SL50 treatment, bright green spots were visualized indicating an early stage of cell death together with green viable cells. In the case of B16F10, G500, and L-SL50 treated samples both green and red colored cells were observed. Treatment of A549 cells with G500 and LSL50 resulted in more necrotic/dead cells (Figure 6; Supplementary Figure 3).

\section{Glycolipid Causes Necrosis in Cancer Cells}

Effect of glycolipids on cancer cells was measured by FACS using Annexin/PI staining. Approximately, 26\% of A549 cells, treated with G500, exhibited necrosis, however, $45 \%$ of the cells showed necrosis when treated with L-SL50. On the other hand, B16 F10 cells showed less number of necrosed cells compared to A549 cells. Only $10 \%$ and $25 \%$ populations showed necrosis when treated with G500 and L-SL50 in B16F10 cell line. MDA-MB231 was the most resistant cell line by exhibiting $11 \%$ and $23 \%$ population of the cells to be necrosed when treated with L-S150 and G500, respectively (Figure 7). Insignificant number of cell populations showed early and late stage of apoptosis in both the compounds used.

\section{Combinatorial Effect of Glycolipids Against the Cancer Cells}

Combinatorial effect of L-SL and Glucolipid was also evaluated against all the three cancer cell lines used in this study. The predetermined $\mathrm{IC}_{90}$ of lactonic SL and Glucolipid against A549 were 70 and $1,000 \mu \mathrm{g} / \mathrm{ml}$, respectively. Whereas, $\mathrm{MIC}_{90}$ of lactonic SL against MDA-MB231 was $70 \mu \mathrm{g} / \mathrm{ml}$. However, $\mathrm{MIC}_{90}$ of Glucolipid against MDA-MB231 and B16F10 was not observed after $24 \mathrm{~h}$ of treatment (Figure 1B). Fractionation inhibitory concentration (FIC) for glycolipids (Lactonic-SL and Glucolipid) was calculated. L-SL and 
A

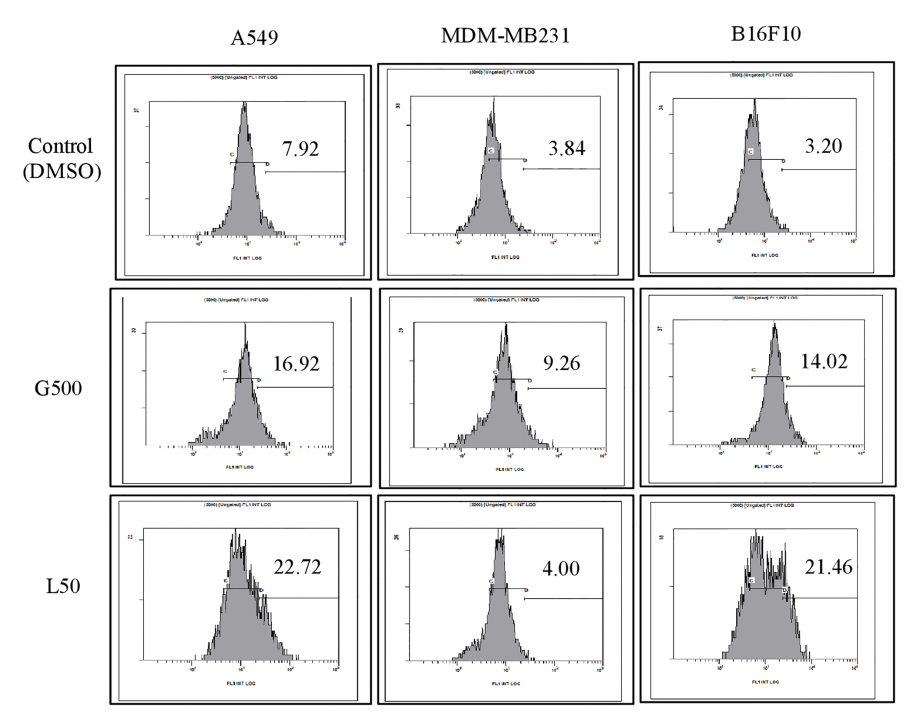

B

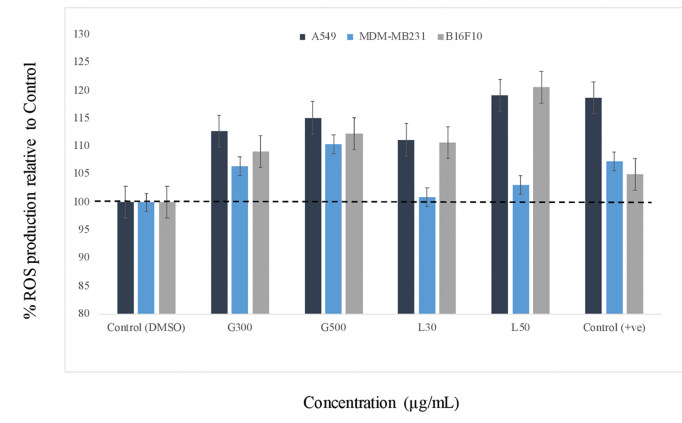

FIGURE 4 | The effect of glycolipids biosurfactant on ROS (Reactive Oxygen Species) production. (A) Flow cytometry (FACS) analysis showing the ROS production at L50 (Lactonic SL $50 \mu \mathrm{g} / \mathrm{mL}$ ) and Glucolipid (G500 $\mu \mathrm{g} / \mathrm{mL}$ ) concentration on different cancerous cell lines. The cells have been treated with the glycolipid for $3 \mathrm{~h}$ and later stained with ROS specific dye H2-DCFDA. (B) The estimation of ROS was also measured by fluorimetric analysis, and the results have been compared with DMSO control. Etoposide was used as a positive control. The experiment has been performed three times on three independent days.

Glucolipid concentration of $0.25 \times \mathrm{MIC}_{90}$ reduced the $\mathrm{MIC}_{90}$ of A549 cells by 4 -folds. Glucolipid at $0.125 \times \mathrm{MIC}_{90}$ and L-SL at 0.50 concentration $\times \mathrm{MIC}_{90}$ reduced the $\mathrm{MIC}_{90}$ of $\mathrm{MDM}-\mathrm{MB}$ 231 by eight and two folds, respectively. Whereas, glucolipid and L-SL at $0.25 \times \mathrm{MIC}_{90}$ reduced the $\mathrm{MIC}_{90}$ of $\mathrm{B} 16 \mathrm{~F} 10$ by 4 fold and more than 4, respectively. After the FIC calculation, Fractionation inhibitory concentration index (FICI) was calculated to determine the nature of interaction between the test compounds. L-SL and Glucolipid exhibited synergistic effect against A549 cells whereas additive effect against MDA-MB231 and B16F10 cell lines. The FICI value of L-SL and Glucolipid in combination against A549, MDA-MB231, and B16F10 were 0.5, 0.625 and $\leq 1$, respectively (Table 2 ).

\section{DISCUSSION}

In spite of advancements achieved in combating cancers, resistance to classical chemotherapeutic agents continue to be a major obstacle in cancer therapies and accountable for most relapses, one of the major causes of death in cancer $(28,29)$. Moreover, the effectiveness has often been limited by toxicities on normal tissues/cells, poor solubility and stability, and limited bio-distribution $(30,31)$. Thus, it is vital to create alternative efficient formulations that can address the above mentioned challenges and provide selective targeting of cancer cells without significant damage to the viability of healthy cells.

Interest in biosurfactants has been increased from past few years due to their physiochemical as well as biomedical properties (32). Glycolipids BSs have great impact in the field of medical sciences and proven to have better effects than other BSs (4). Rhamnolipid, Sophorolipid, mannosylerythritol lipid with other glycolipids have been reported to possess antimicrobial, anticancer, and antiadhesive properties (3, 7, 33). Therefore, we attempted to evaluate anticancer potential of certain glycolipids of natural origin as shown in Figure 1A, i.e., bolalipid, glucolipid, acidic-sophorolipid, and lactonicsophorolipid and explored their possible mode of action in 
A549

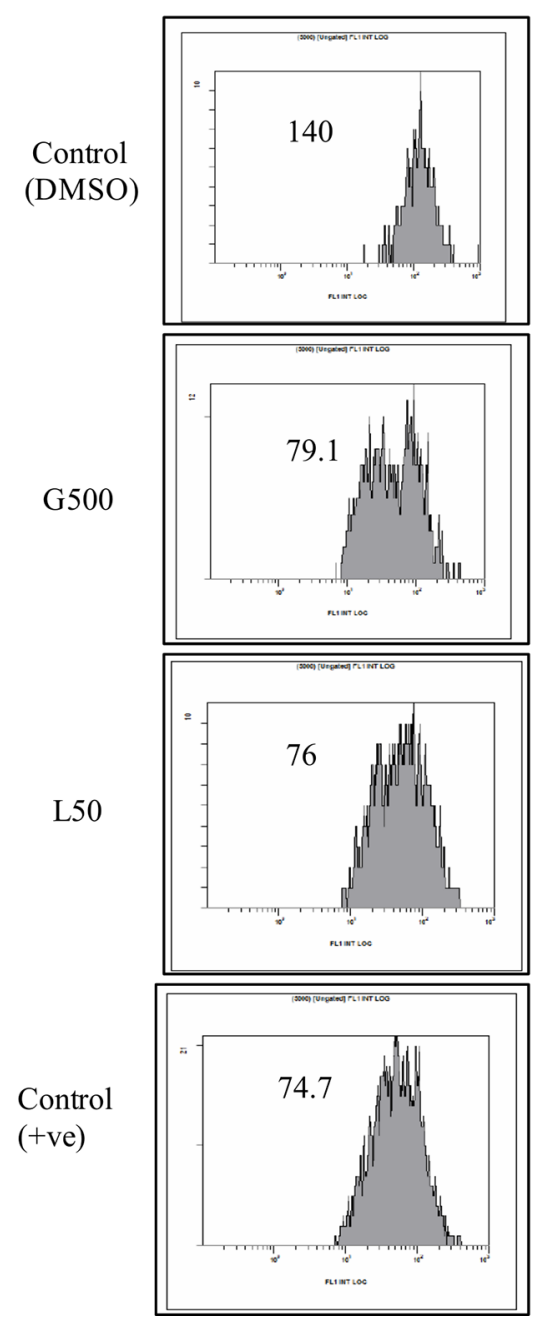

MDM-MB231
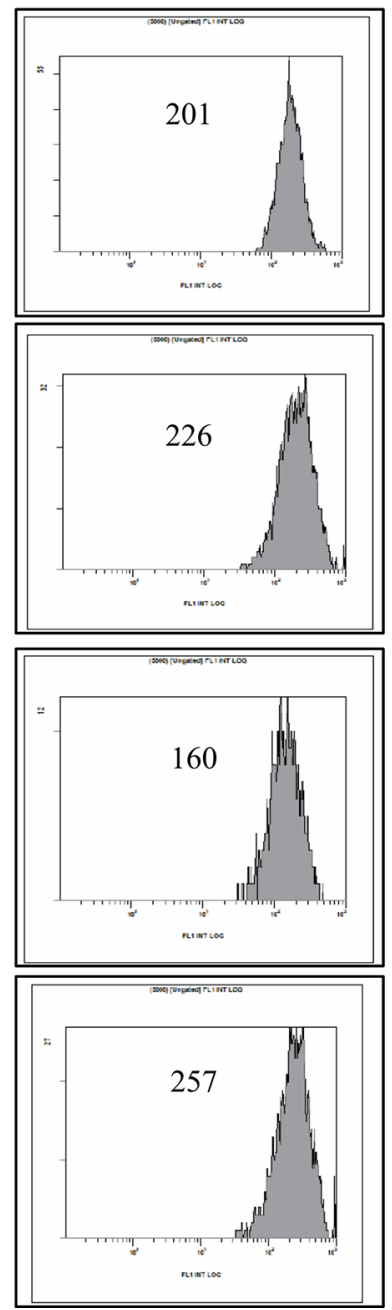

B16F 10
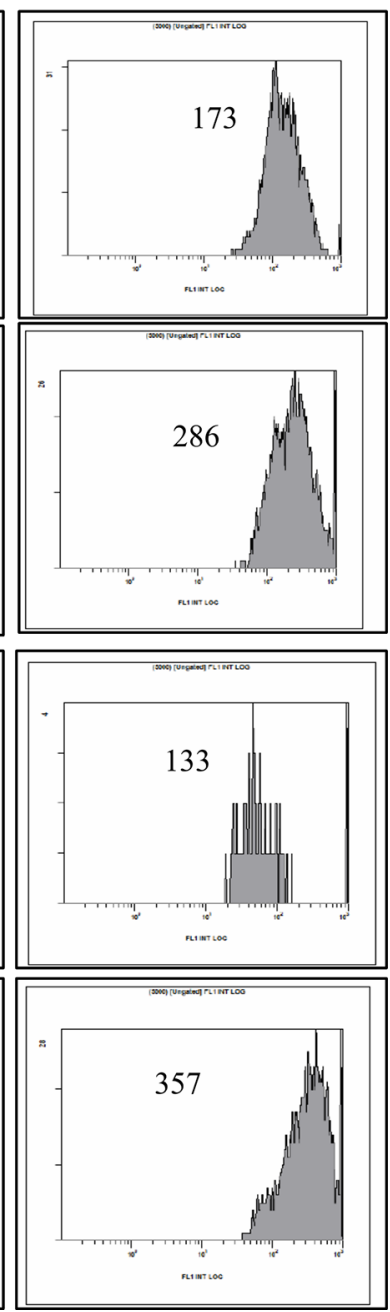

FIGURE 5 | The effect of glycolipids on mitochondrial membrane potential (MMP) on different cancer cell lines. L50 (Lactonic SL 50 $\mu$ g/mL) and Glucolipid (G500 $\mu$ g/ $\mathrm{mL}$ ) concentration were used to study glycolipid effect on MMP change. MMP was determined by the retention of the dye 3 , 3'- Dihexyloxacarbocyanine iodide (DiOC6) in cell and as measured by flow cytometry in FL-1 channel. Etoposide was used as a positive control. The experiment has been performed three times on three independent days.

cancer cell. In the present study, lactonic-sophorolipid (L-SL) and Glucolipid exerted cytotoxic effects against the cancer cell lines (A549, MDM-MB 231, and B16F10) but bolalipid (Bola) and acidic-sophorolipid (A-SL) did not show any effect. Shao et al. (10) have also reported non-cytotoxicity of A-SL on esophageal cancer cells (11). Bolalipid is one of the class of bolaamphiphilic compounds having two sophorose sugars attached at both ends of the lipid chain (34). On the other hand, there is no report on cell cytotoxicity using bolalipids in vitro as well as in vivo, makes them advantageous to be used in drug/gene delivery nano-carriers $(34,35)$.

Out of the four tested glycolipids, L-SL has shown better effects followed by glucolipid. A similar report for L-SL, produced by Wickerhamiella domercqiae, on different cancer cell lines has been published (9). Nevertheless, no anticancer activity of glucolipid is reported in the literature. In our study, the $\mathrm{IC}_{50}$ of glucolipid is much higher than the L-SL in all the cell lines used. Moreover, complete killing of the cells was not observed for glucolipid even at the highest concentration used. The degree of effectiveness of glycolipids is thought to be due to the presence of different head groups attached to the lipid chain. Shah et al. (32) observed enhanced antibacterial activity of L-SL when the cells were grown in different carbohydrate containing media (7). Cell viability of control human fibroblast cells (MRC5) was also checked in the presence of glycolipids (Supplementary Figure 1). For L-SL However, moderate cytotoxiciy was found at the highest concentration $(100 \mu \mathrm{g} / \mathrm{ml})$ of L-SL used after a treatment of $24 \mathrm{~h}$. After $48 \mathrm{~h}$ of treatment, $\mathrm{IC}_{50}$ value was $90 \mu \mathrm{g} / \mathrm{ml}$ for MRC5 cells whereas at this concentration, only $10 \%$ cell viability was observed for all 


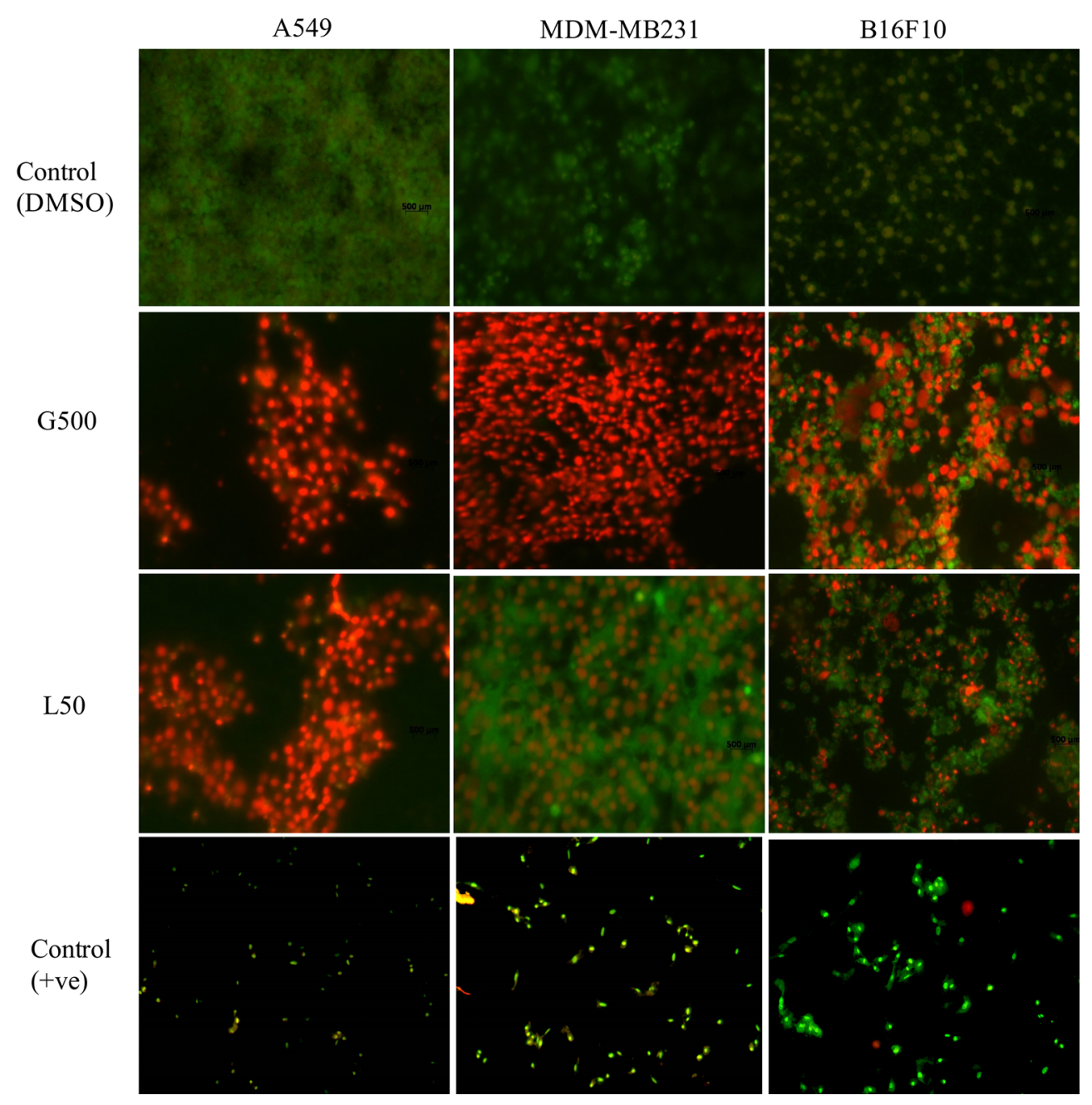

FIGURE 6 | Acridine orange (AO) and ethidium bromide (EB) staining of cancerous cells after treatment of glycolipids. L50 (Lactonic SL $50 \mu \mathrm{g} / \mathrm{mL}$ ) and Glucolipid (G500 $\mu \mathrm{g} / \mathrm{mL}$ ) concentration were used to study glycolipid effect on AO/EB staining. Photograph shows the merged images of AO and EB (60X magnification). Red spots showed necrotic bodies, whereas dark green spots showed the appearance of early stage of apoptosis. The experiment has been performed three times on three independent days.

other cancer cells except B16F10 (i.e., 30\% viability). For glucolipid, $\mathrm{IC}_{50}$ value against MRC-5 was $550 \mu \mathrm{g} / \mathrm{ml}$ and 400 $\mu \mathrm{g} / \mathrm{ml}$ for $24 \mathrm{~h}$ and $48 \mathrm{~h}$ of treatment, respectively and considered to be toxic for normal cells whereas L-SL was safe. Findings from other researachers also suggested the safe use of lactonic-SL (10).

Cancer cell posses a broad range of migration and invasion mechanisms (36). In recent time, it has led therapeutics against the cancer cells progression to be failed in clinical trials (7). Therefore, we also investigated the effect of L-SL and glucolipid on A549, MDA-MB231 and B16 F10 cell migration in vitro. The result showed that both compounds effectively inhibited the cell migration after $24 \mathrm{~h}$ and $48 \mathrm{~h}$ of treatments. MDA-MB231 showed highest resistance followed by A549 and B16F10. Huang et al. (37) have reported that brazilein, a compound isolated from Caesalpinia sappan L., inhibited the migration of
MDA-MB231 cell by inhibiting the expression of matrix metalloproteinase-2 (MMP-2). Matrix metalloproteinase is considered to play a crucial role in the cell migration in other cancer cells $(37,38)$. Another important factor for cell migration is attributed to actin cytoskeleton, which are upregulated in invasive and metastasis cancer cells (39). We observed that LSL and Glucolipid disrupted the existing network of actin filaments and thereby inhibited the cell migration. Similarly, Senderowicz et al. (40) reported that jasplakinolide, a cyclodepsipeptide, inhibited the migration of PC3 cells by disrupting actin cytoskeleton. The actin cytoskeleton is a physiological regulator of ROS release from mitochondria, and a key element in the upstream activation of cell death pathways (41). ROS are formed as a natural by-product of the normal metabolism of oxygen and have an important role in celluler 
A549

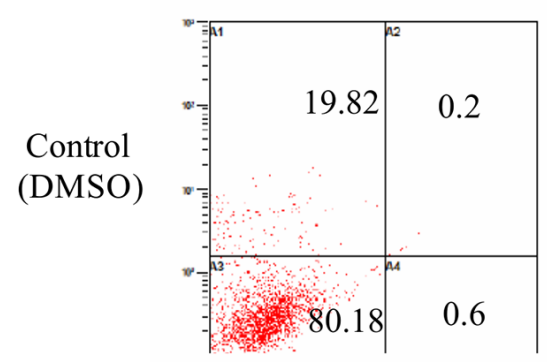

G500
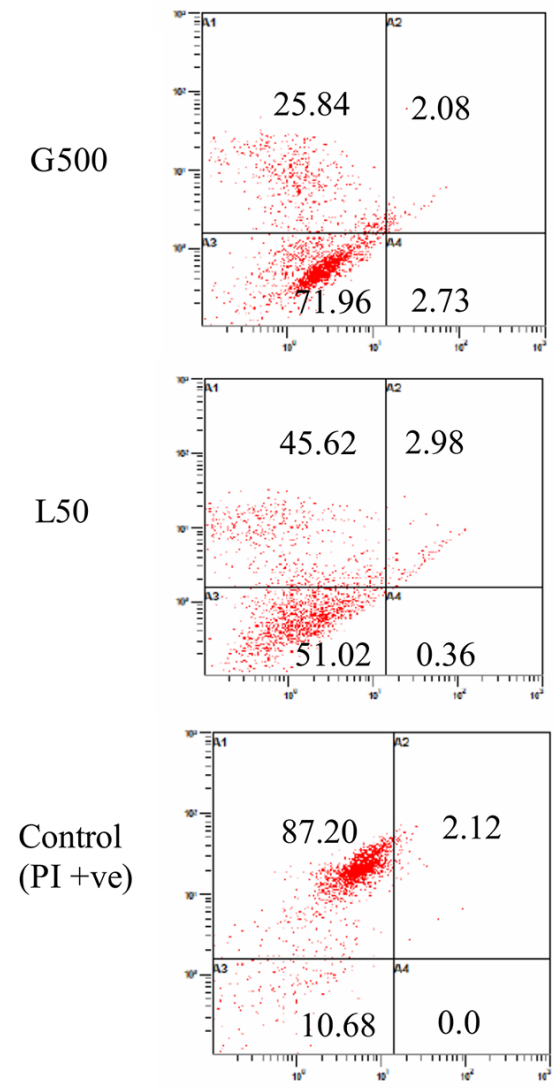

MDM-MB231
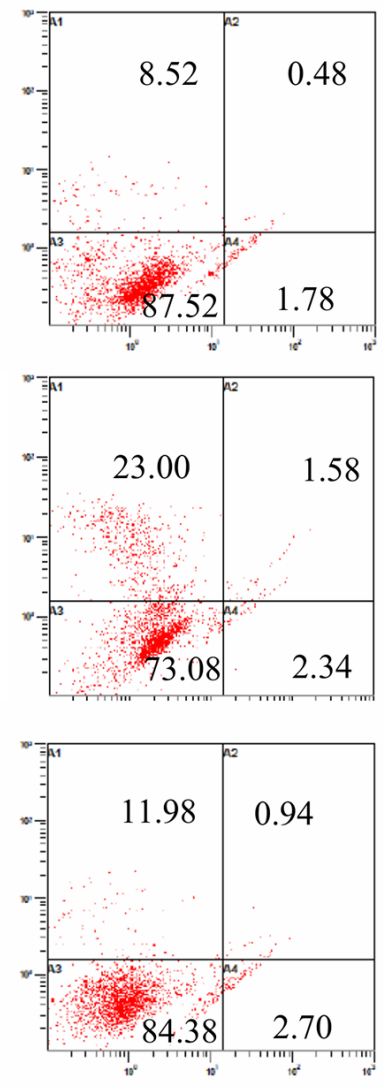

-......n.
B16F10
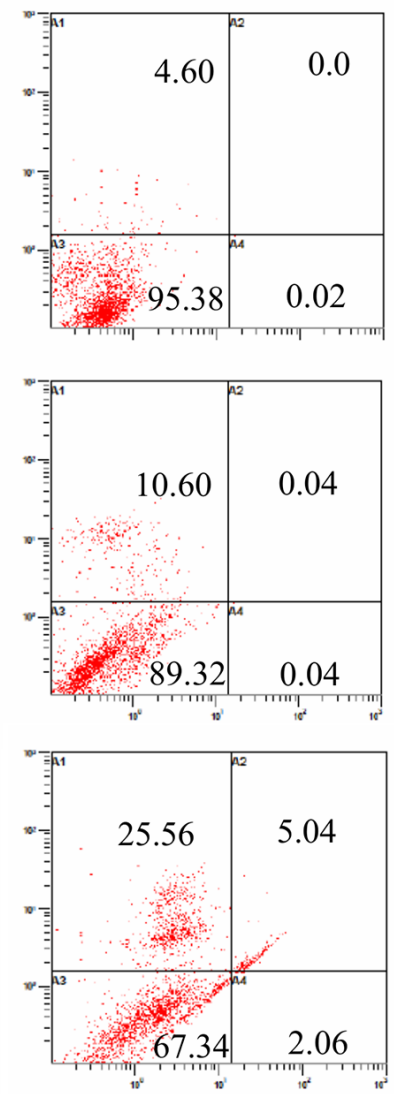

FIGURE 7 | Flow cytometry (FACS) analysis of Annexin V and PI stained cancer cells after treatment with glycolipids. L50 (Lactonic SL 50 $\mu$ g/ml) and Glucolipid (G500 $\mu \mathrm{g} / \mathrm{ml}$ ) concentration were used to study glycolipid effect on apoptosis/necrosis. Lower left panel of each quadrant represent untreated control; upper left panel shows the necrotic bodies, whereas upper and lower right panel showed the late and early stage of apoptosis. Samples were acquired at the FL-1 channel. For PI positive control, we heat-treated $\left(95^{\circ} \mathrm{C}\right)$ the sample (all three cell lines, only A549 treated samples have been shown) for 15 min and later stained with Annexin $\mathrm{V}$ propidium iodide. The experiment has been performed three times on three independent days.

TABLE 2 | The combinatorial effect of glycolipids (lactonic sophorolipid and glucolipid) on different cancer cell lines.

\begin{tabular}{lcccc}
\hline Cell lines & \multicolumn{2}{c}{ FIC } & FICI \\
\hline A 549 & Glu & SL & 0.5 \\
MDA-MB231 & 0.25 & 0.25 & \\
& GIU & SL & 0.625 \\
B16F10 & 0.125 & 0.5 & \\
& Glu & SL & 1 \\
& 0.5 & 0.5 &
\end{tabular}

homeostasis and signaling, but during the stress condition, the level of ROS increases dramatically. Therefore, we estimated the production of ROS in the presence of glycolipids using $\mathrm{H}_{2}$ DCFDA dye. DCFH-DA can easily pass through the cell membrane and is de-esterified by intracellular esterases to the nonfluorescent polar derivative DCFH, which is oxidized to highly fluorescent dichlorofluorescein (DCF) in the presence of ROS. Interestingly, ROS was produced by all the cancer cells used, except MDA-MB 231. We speculate that it could be due to 
its higher resistance. L-SL induced more ROS production compared to the glucolipid. Similar findings for ROS production in the presence of L-SL on breast cancer cell line, were reported by Ribeiro et al. (42). It has been reported in the literature that mitochondria are the vital source for the ROS production and cellular homeostasis (43). This homeostasis is changed during the stress conditions in the form of change in the MMP. Therefore, we measured the MMP of cell lines in the presence of glycolipids, and found a significant change in the potential difference when compared to the vehicle control (DMSO).

Furthermore, the mechanism of cell death was further explained by using acridine orange and ethidium bromide dual staining and flow cytometry experiments. Acridine orange is a green vital dye which stains the live and dead cells and emits green florescence when binds to the double helix, whereas ethidium bromide stains only dead cells and emits red florescence. Early apoptotic bodies appear as bright green spots with condensed or fragmented chromatin and late apoptotic bodies display condensed and fragmented orange nucleus (44). We found that both L-SL and Glucolipid caused cell death in all the three cell lines. Most of the cells appeared red, however, a few cells showed the bright green spots, which indicated that the cells underwent necrosis. Moreover, to assure necrosis dependent killing, we further examined it by flow cytometry experiments using Annexin/PI staining. During the apoptosis, the membrane phospholipid phosphatidylserine (PS) is translocated from inner to the outer leaflet of the plasma membrane. Annexin has the capability to bind the surface exposed PS and give positive signals whereas PI only enters to the dead or damaged cells and excluded by the healthy/live cells. We observed high percentage of cell population appeared to be PI positive, which has indicated the necrosis in the cells. There are various treatments used for anticancer therapy which also may cause necrosis in tumor cells (45). Outcomes of our study showed ROS-dependent necrosis in the cancer cells. Some reports also suggested possible role of kinase receptor-interacting protein (RIP1) in ROS-dependent necrosis $(46,47)$. We hypothesize that in the present study, it might be possible that L-SL and Glucolipid could induce ROS-dependent necrosis via activation of RIP1 and causes cell death in cancer cells.

Many conventional chemotherapeutic anticancer agents kill cancer cells by directly damaging their DNA, which has the problem of non-specificity and relatively high toxicity (29). In this regard, combinatorial therapy is considered best to reduce the toxicity and increase the efficacy of the compounds (48). The combination of non-steroidal inflammatory drugs was shown to act synergistically in the ovarian cancer cell line (49). In the present study, we examined the combinatorial effect of L-SL and Glucolipid on lung (A549), breast cancer (MDA-MB231) and mouse melanoma (B16F10) cell lines. Interestingly, both the compounds act synergistically against A549 cells as 4-folds reductions were observed. However, additive effects were seen against B16F10 and MDA-MB231 cell lines as they reduced the $\mathrm{IC}_{90}$ value by 2 -folds only. Synergistic interaction of curcurbitacin B with other chemotherapeutic drugs was also reported on A549 cells and proven better than the available drugs (50). Similar results for synergistic interaction on triple negative breast cell line by rapamycin and lapatinib has also been reported by Liu et al. (51). These two glycolipids interacted synergistically/ additively on the cancer lines, therefore, could be used at very low concentration to avoid normal cell toxicity, and with increased efficacy on cancer cells.

In recent decades, more and more targeted drugs have been used to specifically target/prevent changes that push cancer growth and spread. However, initial outcomes of these drugs are quite effective, a large number of patients develop resistance as medication progresses (29). For example, 30\%-55\% of patients with non-small cell lung cancer (NSCLC) relapse and die from the disease subsequently (52). The 50\%-70\% of ovarian adenocarcinomas reoccur within 1 year post-surgery and associated chemotherapy (53). The multiple targets in combination would tackle the problem of emerging drug resistance and relapses. Furthermore, poor pharmacokinetic characteristics of anticancer drugs could also be overcome as these biosurfactants have been proven to show easy bioavailability and drug delivery (1, 4, 5, 28, 29, 54, 55). However, the pathways for glycolipids induced necrosis need to be further elucidated. Present findings suggest that lactonicsophorolipid and glucolipid could be a valuable addition to search for novel anticancer therapeutics.

\section{Statistical Evaluation}

All experiments were performed in triplicate and on three different days. All data were expressed as mean values with the corresponding standard deviations (SD). Statistical significance between treated and control groups was analyzed by Student's ttest (two-tailed, unequal variance). A p-value of $<0.05$ was considered statistically significant.

\section{DATA AVAILABILITY STATEMENT}

The original contributions presented in the study are included in the article/Supplementary Material. Further inquiries can be directed to the corresponding authors.

\section{AUTHOR CONTRIBUTIONS}

FH designed and performed the experiments and wrote the manuscript. MSAK analyzed and reviewed the data, and revised the manuscript. All authors contributed to the article and approved the submitted version.

\section{SUPPLEMENTARY MATERIAL}

The Supplementary Material for this article can be found online at: https://www.frontiersin.org/articles/10.3389/fonc.2021. 622470/full\#supplementary-material 


\section{REFERENCES}

1. Marchant R, Banat IM. Biosurfactants: a sustainable replacement for chemical surfactants? Biotechnol Lett (2012) 34:1597-605. doi: 10.1007/s10529-0120956-x

2. Mulligan CN. Environmental applications for biosurfactants. Environ Pollut (2005) 133:183-98. doi: 10.1016/j.envpol.2004.06.009

3. Kitamoto D, Isoda H, Nakahara T. Functions and potential applications of glycolipid biosurfactants-from energy-saving materials to gene delivery carriers. J Biosci Bioeng (2002) 94:187-201. doi: 10.1016/S1389-1723(02) 80149-9

4. Cortés-Sánchez A, Hernández-Sánchez H, Jaramillo-Flores ME. Biological activity of glycolipids produced by microorganisms: New trends and possible therapeutic alternatives. Microbiol Res (2013) 168:22-32. doi: 10.1016/ j.micres.2012.07.002

5. Rodrigues LR, Teixeira JA. Biomedical and therapeutic applications of biosurfactants. Adv Exp Med Biol (2010) 672:75-87. doi: 10.1007/978-14419-5979-9_6

6. Kitamoto D, Yanagishita H, Shinbo T, Nakane T, Kamisawa C, Nakahara T. Surface active properties and antimicrobial activities of mannosylerythritol lipids as biosurfactants produced by Candida antarctica. J Biotechnol (1993) 29:91-6. doi: 10.1016/0168-1656(93)90042-L

7. Haque F, Sajid M, Cameotra SS, Battacharyya MS. Anti-biofilm activity of a sophorolipid-amphotericin B niosomal formulation against Candida albicans. Biofouling (2017) 33:768-79. doi: 10.1080/08927014.2017.1363191

8. Zhao X, Wakamatsu Y, Shibahara M, Nomura N, Geltinger C, Nakahara T, et al. Mannosylerythritol lipid is a potent inducer of apoptosis and differentiation of mouse melanoma cells in culture. Cancer Res (1999) 59:482-6.

9. Chen J, Song X, Zhang H, Qu YB, Miao JY. Sophorolipid produced from the new yeast strain Wickerhamiella domercqiae induces apoptosis in H7402 human liver cancer cells. Appl Microbiol Biotechnol (2006) 72:52-9. doi: 10.1007/s00253-005-0243-z

10. Fu SL, Wallner SR, Bowne WB, Hagler MD, Zenilman ME, Gross R, et al. Sophorolipids and their derivatives are lethal against human pancreatic cancer cells. J Surg Res (2008) 148:77-82. doi: 10.1016/j.jss.2008.03.005

11. Shao L, Song X, Ma X, Li H, Qu Y. Bioactivities of sophorolipid with different structures against human esophageal cancer cells. J Surg Res (2012) 173:28691. doi: 10.1016/j.jss.2010.09.013

12. Burgos-Díaz C, Martín-Venegas R, Martínez V, Storniolo CE, Teruel JA, Aranda FJ, et al. In vitro study of the cytotoxicity and antiproliferative effects of surfactants produced by Sphingobacterium detergens. Int J Pharm (2013) 453:433-40. doi: 10.1016/j.ijpharm.2013.06.029

13. Fracchia L, Banat JJ, Cavallo M, Ceresa C, Banat IM. Potential therapeutic applications of microbial surface-active compounds. AIMS Bioeng (2015) 2:144-62. doi: 10.3934/bioeng.2015.3.144

14. Haque F, Verma NK, Alfatah M, Bijlani S, Bhattacharyya MS. Sophorolipid exhibits antifungal activity by ROS mediated endoplasmic reticulum stress and mitochondrial dysfunction pathways in Candida albicans. RSC Adv (2019) 9:41639-48. doi: 10.1039/C9RA07599B

15. Haque F, Alfatah M, Ganesan K, Bhattacharyya MS. Inhibitory Effect of Sophorolipid on Candida albicans Biofilm Formation and Hyphal Growth. Sci Rep (2016) 6:23575. doi: 10.1038/srep23575

16. Samadi N, Abadian N, Ahmadkhaniha R, Amini F, Dalili D, Rastkari N, et al. Structural characterization and surface activities of biogenic rhamnolipid surfactants from Pseudomonas aeruginosa isolate MN1 and synergistic effects against methicillin-resistant Staphylococcus aureus. Folia Microbiol (2012) 57:501-8. doi: 10.1007/s12223-012-0164-z

17. Gudiña EJ, Rangarajan V, Sen R, Rodrigues LR. Potential therapeutic applications of biosurfactants. Trends Pharmacol Sci (2013) 34:667-75. doi: 10.1016/j.tips.2013.10.002

18. Organization WH. Global health risks: mortality and burden of disease attributable to selected major risks. World Health Organ (2009). Available at: https://www.who. int/healthinfo/global_burden_disease/GlobalHealthRisks_report_full.pdf

19. Ferlay J, Shin HR, Bray F, Forman D, Mathers C, Parkin DM. Estimates of worldwide burden of cancer in 2008: GLOBOCAN 2008. Int J Cancer J Int $d u$ Cancer (2010) 127:2893-917. doi: 10.1002/ijc.25516

20. Muvaffak A, Gurhan I, Gunduz U, Hasirci N. Preparation and characterization of a biodegradable drug targeting system for anticancer drug delivery: microsphere-antibody conjugate. J Drug Targeting (2005) 13:151-9. doi: $10.1080 / 10611860400029069$

21. Gottesman MM. Mechanisms of cancer drug resistance. Annu Rev Med (2002) 53:615-27. doi: 10.1146/annurev.med.53.082901.103929

22. Saerens K, Van Bogaert I, Soetaert W, Vandamme E. Production of glucolipids and specialty fatty acids from sophorolipids by Penicillium decumbens naringinase: Optimization and kinetics. Biotechnol J (2009) 4:517-24. doi: 10.1002/biot.200800209

23. Delbeke EIP, Everaert J, Lozach O, Le Gall T, Berchel M, Montier T, et al. ACS Sustainable. Chemistry \& Engineering (2018). Vol. 7 p. 8992-9005.

24. Liang C-C, Park AY, Guan J-L. In vitro scratch assay: a convenient and inexpensive method for analysis of cell migration in vitro. Nat Protoc (2007) 2:329-33. doi: 10.1038/nprot.2007.30

25. Liu H, Ma Y, Pagliari LJ, Perlman H, Yu C, Lin A, et al. TNF-alpha-induced apoptosis of macrophages following inhibition of NF-kappa B: a central role for disruption of mitochondria. J Immunol (Baltimore Md 1950) (2004) 172:1907-15. doi: 10.4049/jimmunol.172.3.1907

26. Kasibhatla S, Amarante-Mendes GP, Finucane D, Brunner T, Bossy-Wetzel E, Green DR. Acridine Orange/Ethidium Bromide (AO/EB) Staining to Detect Apoptosis. CSH Protoc (2006) 2006. doi: 10.1101/pdb.prot4463

27. Rieger AM, Nelson KL, Konowalchuk JD, Barreda DR. Modified Annexin V/ Propidium Iodide Apoptosis Assay For Accurate Assessment of Cell Death. J Visualized Exp JoVE (2011) 24(50):2597. doi: 10.3791/2597

28. Housman G, Byler S, Heerboth S, Lapinska K, Longacre M, Synder N, et al. Drug Resistance in Cancer: an Overview. Cancers (Basel) (2014) 6:1769-92. doi: $10.3390 /$ cancers 6031769

29. Wang X, Zhang H, Chen X. Drug Resistance and Combating Drug Resistance in Cancer. Cancer Drug Resistance (2019) 2:141-60. doi: 10.20517/cdr.2019.10

30. Bae YH. Drug Targeting and Tumor Heterogeneity. J Control (2009) 133:2-3. doi: 10.1016/j.jconrel.2008.09.074

31. Navya PN, Kaphle A, Srinivas SP, Bhargava SK, Rotello VM, Daima HK. Current Trends and Challenges in Cancer Management and Therapy Using Designer Nanomaterials. Nano Convergence (2019) 6:23. doi: 10.1186/s40580019-0193-2

32. Rodrigues L, Banat IM, Teixeira J, Oliveira R. Biosurfactants: potential applications in medicine. J Antimicrobial Chemother (2006) 57:609-18. doi: $10.1093 / \mathrm{jac} / \mathrm{dk} 1024$

33. Sotirova A, Spasova D, Vasileva-Tonkova E, Galabova D. Effects of rhamnolipid-biosurfactant on cell surface of Pseudomonas aeruginosa. Microbiol Res (2009) 164:297-303. doi: 10.1016/j.micres.2007.01.005

34. Fariya M, Jain A, Dhawan V, Shah S, Nagarsenker MS. Bolaamphiphiles: A Pharmaceutical Review. Advanced Pharm Bull (2014) 4:483-91. doi: 10.5681/ apb.2014.072

35. Meister A, Blume A. Self-assembly of bipolar amphiphiles. Curr Opin Colloid Interface Sci (2007) 12:138-47. doi: 10.1016/j.cocis.2007.05.003

36. Friedl P, Wolf K. Tumour-cell invasion and migration: diversity and escape mechanisms. Nat Rev Cancer (2003) 3:362-74. doi: 10.1038/nrc1075

37. Huang C-H, Lu S-H, Chang C-C, Thomas PA, Jayakumar T, Sheu J-R. Hinokitiol, a tropolone derivative, inhibits mouse melanoma (B16-F10) cell migration and in vivo tumor formation. Eur J Pharmacol (2015) 746:148-57. doi: 10.1016/j.ejphar.2014.11.011

38. Lin S-S, Lai K-C, Hsu S-C, Yang J-S, Kuo C-L, Lin J-P, et al. Curcumin inhibits the migration and invasion of human A549 lung cancer cells through the inhibition of matrix metalloproteinase-2 and -9 and Vascular Endothelial Growth Factor (VEGF). Cancer Lett (2009) 285:127-33. doi: 10.1016/ j.canlet.2009.04.037

39. Yamaguchi H, Condeelis J. Regulation of the actin cytoskeleton in cancer cell migration and invasion. Biochim Biophys Acta (BBA) - Mol Cell Res (2007) 1773:642-52. doi: 10.1016/j.bbamcr.2006.07.001

40. Senderowicz AM, Kaur G, Sainz E, Laing C, Inman WD, Rodriguez J, et al. Jasplakinolide's inhibition of the growth of prostate carcinoma cells in vitro with disruption of the actin cytoskeleton. J Natl Cancer Inst (1995) 87:46-51. doi: 10.1093/jnci/87.1.46

41. Gourlay CW, Ayscough KR. The actin cytoskeleton: a key regulator of apoptosis and ageing? Nat Rev Mol Cell Biol (2005) 6:583-9. doi: 10.1038/ nrm1682

42. Ribeiro IAC, Faustino CMC, Guerreiro PS, Frade RFM, Bronze MR, Castro MF, et al. Development of novel sophorolipids with improved cytotoxic 
activity toward MDA-MB-231 breast cancer cells. J Mol Recognit (2015) 28:155-65. doi: 10.1002/jmr.2403

43. Murphy Michael P. How mitochondria produce reactive oxygen species. Biochem J (2009) 417:1-13. doi: 10.1042/BJ20081386

44. Wu J, Yi W, Jin L, Hu D, Song B. Antiproliferative and cell apoptosis-inducing activities of compounds from Buddleja davidii in Mgc-803 cells. Cell Div (2012) 7:20. doi: 10.1186/1747-1028-7-20

45. Sergey YP, Vladimir LG. Mechanisms of Tumor Cell Necrosis. Curr Pharm Des (2010) 16:56-68. doi: 10.2174/138161210789941793

46. Brown MF, Leibowitz BJ, Chen D, He K, Zou F, Sobol RW, et al. Loss of Caspase-3 sensitizes colon cancer cells to genotoxic stress via RIP1-dependent necrosis. Cell Death Dis (2015) 6:e1729. doi: 10.1038/cddis.2015.104

47. Kim SK, Seo G, Oh E, Jin S-H, Chae GT, Lee S-B. Palmitate induces RIP1dependent necrosis in RAW 264.7 cells. Atherosclerosis (2012) 225:315-21. doi: 10.1016/j.atherosclerosis.2012.09.021

48. Al-Lazikani B, Banerji U, Workman P. Combinatorial drug therapy for cancer in the post-genomic era. Nat Biotechnol (2012) 30:679-92. doi: 10.1038/nbt.2284

49. Zerbini LF, Tamura RE, Correa RG, Czibere A, Cordeiro J, Bhasin M, et al. Combinatorial Effect of Non-Steroidal Anti-inflammatory Drugs and NF-kB Inhibitors in Ovarian Cancer Therapy. PloS One (2011) 6:e24285. doi: 10.1371/journal.pone.0024285

50. Marostica LL, Silva IT, Kratz JM, Persich L, Geller FC, Lang KL, et al. Synergistic Antiproliferative Effects of a New Cucurbitacin B Derivative and Chemotherapy Drugs on Lung Cancer Cell Line A549. Chem Res Toxicol (2015) 28:1949-60. doi: 10.1021/acs.chemrestox.5b00153

51. Liu T, Yacoub R, Taliaferro-Smith LD, Sun S-Y, Graham TR, Dolan R, et al. Combinatorial Effects of Lapatinib and Rapamycin in Triple-Negative Breast
Cancer Cells. Mol Cancer Ther (2011) 10:1460-9. doi: 10.1158/15357163.MCT-10-0925

52. Uramoto H, Tanaka F. Recurrence after surgery in patients with NSCLC. Transl Lung Cancer Res (2014) 3:242-9. doi: 10.3978/j.issn.22186751.2013.12.05

53. Castells M, Thibault B, Delord JP, Couderc B. Implication of tumor microenvironment in chemoresistance: tumor-associated stromal cells protect tumor cells from cell death. Int J Mol Sci (2012) 13:9545-71. doi: 10.3390/ijms 13089545

54. Faivre V, Rosilio V. Interest of glycolipids in drug delivery: from physicochemical properties to drug targeting. Expert Opin Drug Delivery; (2010) 7:1031-48. doi: 10.1517/17425247.2010.511172

55. Ohadi M, Shahravan A, Dehghannoudeh N, Eslaminejad T, Banat IM, Dehghannoudeh G. Potential Use of Microbial Surfactant in Microemulsion Drug Delivery System: A Systematic Review. Drug Des Dev Ther (2020) 14:541-50. doi: 10.2147/DDDT.S232325

Conflict of Interest: The authors declare that the research was conducted in the absence of any commercial or financial relationships that could be construed as a potential conflict of interest.

Copyright (C) 2021 Haque, Khan and AlQurashi. This is an open-access article distributed under the terms of the Creative Commons Attribution License (CC BY). The use, distribution or reproduction in other forums is permitted, provided the original author(s) and the copyright owner(s) are credited and that the original publication in this journal is cited, in accordance with accepted academic practice. No use, distribution or reproduction is permitted which does not comply with these terms. 